Jpn. J. Med. Mycol.

Vol. 26, 233-237, 1985

ISSN 0583-0516

カンジダによるマウスの実験的動脈炎発生と $\operatorname{IgE}$ 抗体の関連性

村田 久雄 飯島 肇 直江 史郎* 跡部 俊彦*

東邦大学医学部公衆衛生学教室

* 東邦大学大橋病院病理部

〔受付：2 月 7 日, 1985 年]

川崎病患児では，その急性期に一過性の IgE 抗体上昇がみられることが知られている.

我々はこれまでに作成し得たカンジダによるマウスの実験的動脈炎モデルに拈ける, 抗カンジダ IgE 抗体量を, PCAの手法を用いて測定すると共に，動脈炎発生頻度との関連性を検討した。その結果，こ の血管炎モデルに损いても, 抗カンジダ $\operatorname{IgE}$ 抗体が証明され（PCA 価 1), この際, カンジダ抗原に百 日咳菌ワクチンを添加，感作すると同 $\operatorname{IgE}$ 抗体が増強されることを認めた。しかし，この百日咳菌ワク チンの IgE 抗体増強効果は, その接種時期により異なり, 抗原の第 1 次接種時に添加, 免度された群 (PCA 価 80) は, 第 2 次接種時に添加, 免疫された群 (PCA 価 10) に比し, 遙かに高い IgE 抗体価を 示した。 また，動脈炎の発生頻度は，それぞれの免疫群で 40,87 及び $55 \%$ と, PCA 価と平行した発生 率を示した。これに反し, 抗原を第 2 次接種時に 1 round のみ接種した群では, PCA 及び動脈炎の発生 は何れも陰性であった。これらの成績は $\operatorname{IgE}$ 抗体と動脈炎発生との間に, 何らかの関連性が存在するも のと考学る。

また, IgE 抗体価の経時的推移を検索した結果，その存在は抗原接種後 3 日でみられ（PCA 価 20), 10 日でピークに達し(PCA 価 80)，24 日には急激に減少した（PCA 1)。これは川崎病患児にみられる $\mathrm{IgE}$ 抗体の経時的推移と類似するものと思われる.

Key words : カンジダ (candida), 動脈炎 (arteritis), IgE

小児に屢々突然死をきたすことで，また，その後遺 症が成人後にも及ぶことが強く懸念されることで, 社 会的にも大きな関心がもたれている川崎病の病因は, 今日に至るも未だ不明であるが，我々はこれ委で，川 崎病患児から分離された Candida albicans を，ある条 件の下でマウスに接種すると，冠動脈を中心とした系 統的血管炎が惹起されることを見出し，これら実験的 血管炎が病理組織学的に，また，発生部位的に川崎病 剖検例でみられる血管病変と極めて類似することを明 らかにしてきた ${ }^{1 \sim 5)}$ 。たた，本実験法は再現性が極めて 高く, 系統的血管病変, とくに川崎病に関連した動物 モデルとして評価されつつある ${ }^{6,7)}$.

川崎病患児では，その急性期に $\operatorname{IgE}$ 抗体が高值に見 出されていることから, 今回はこれら実験的動脈炎の 発生機序を免疫学的に解明する一法として, PCA（受

別刷請求先 : 村田 久雄

干 143 東京都大田区大森西 5-21-16

東邦大学医学部公衆衛生学教室
身皮膚アナフィラキシー）の手法を応用し，我々の実 験モデルに怙ける抗カンジダ $\operatorname{IgE}$ 抗体の産生, 並び に, その抗体価の経時的推移を検索すると共に, $\operatorname{IgE}$ 抗 体価と動脈炎発生頻度との関連性を検討した。

\section{材料と方法}

\section{1. 実験動物}

（1）マウス： ddy 系マウス, 雄, 3 週齢(日本生物材 料センター）をマウス，ラット用オリェンタル固型飼 料と水道水で 1 週間, 飼育観察した後, 健康かつ体重 20〜23 g のものを選び実験に供した.

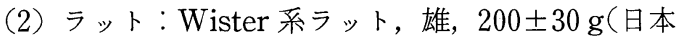
生物材料センター) を上記飼料と水で 1 週間飼育観察 した後, 健康かつ被毛純白なものを選び実験に供した。

\section{2. 抗原の作製}

（1）カンジダ抗原：原法1)に従いカンジダ菌体了ル カリ抽出液を作製した。すなわち，川崎病患児由来の C. albicans, MCLS-2 (ATCC 56811) をサブロー寒天 培地（栄研）に $36^{\circ} \mathrm{C}, 48$ 時間培養して菌体を集め, 減 


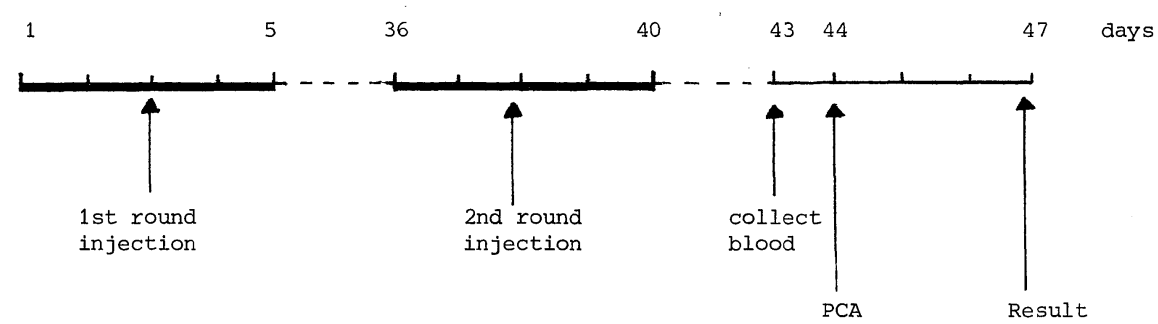

Fig. 1. Experimental schedule (1)

Animal : 1) ddy mouse, 4 weeks, male 2) Wister rat, $200+20 \mathrm{~g}$., male

Antigen : 1) alkali extract of C. albicans, MCLS-2 (ATCC 56811), 2) Vaccine of Bordetella pertussis, Tohama $(1 \mathrm{mg} / \mathrm{ml})$

Immunization : $0.2 \mathrm{ml}$ of antigen intraperitoneally for 5 days each round.

菌生理的食塩水で 3 回洗滌, $1 / 10 \mathrm{~N}-\mathrm{KOH}$ 溶液中 200 $\mathrm{mg} / \mathrm{ml}$ の濃度に再浮遊させて, $37^{\circ} \mathrm{C}$ の恒温槽中で 1 昼 夜, 小ガラス玉と共に振盪抽出した. $10,000 \mathrm{rpm}, 30$ 分 遠心して上清液を採り，1 N-HCl で $\mathrm{pH} 7.2$ と修正し てカンジダ抗原とした.

（2）百日咳菌ワクチン8)：東邦大学医学部公衆衛生 学教室保存の百日咳菌 (東浜株) をボルデジャングー 培地上, $37^{\circ} \mathrm{C}, 48$ 時間培養して集菌し, 減菌生理的食 塩水で 3 回洗滌した。 $0.02 \%$ ェル水銀チオサルチル 酸ソーダ (マーゾニン) 加生理的食塩水中, $1 \mathrm{mg} / \mathrm{ml}$ $\left(10^{9} / \mathrm{ml}\right)$ の濃度にこれらの菌体を再浮遊して百日咳 菌ワクチンとした。 $4{ }^{\circ} \mathrm{C}$ に冷蔵保存し，使用前培養試 験を試み, 成績陰性なることを確認して実験に供した。

\section{3. 抗原感作法と $\operatorname{IgE}$ 抗体測定法}

（1）実験 1：Fig. 1 亿示す如く, ddy 系マウス, 雄, 4 週齢を用い, 抗原 $0.2 \mathrm{ml}$ を腹腔内に 5 日間連続接種 し，36 日目（第 6 週）に再び同接種法を繰返した。実 験群別使用抗原の種類及び実験マウス数は Table 1 に 示す如くである。第 2 次抗原接種後 3 日目，生存する マウスを屠殺, 後大静脈から採血して $\mathrm{PCA}^{9)}$ に供し た。すなわち，採血した血液を各群ごとにまとめ，血 清を分離して各稀釈列を作り，その $0.05 \mathrm{ml}$ をそれぞ れラット背部皮内に接種感作した。同時に対照として $56^{\circ} \mathrm{C}, 2$ 時間加温処理した血清を接種した。 3 日後, 惹起抗原としてカンジダ抗原 $1 \mathrm{ml}$ を Evans blue と共 に, ラット尾静脈から注入し，30 分後, 感作局所皮膚 の青变をもって成績陽性と判定し，その血清最高稀釈 度をPCA 価とした。

（2）実験 $2 ： \operatorname{ddy}$ 系マウス, 雄，4週齢を70 匹使用 し，実験 1，84 A-II群と同じ方法で抗原を接種した。 すなわち，第 1 次にカンジダ抗原と百日咳ワクチンを
Table 1. Group of mice and antigen used

\begin{tabular}{|c|c|c|c|}
\hline Group & $\begin{array}{c}\text { No. of } \\
\text { mice }\end{array}$ & $\begin{array}{l}\text { 1st round } \\
\text { injection }\end{array}$ & $\begin{array}{l}\text { 2nd round } \\
\text { injection }\end{array}$ \\
\hline $84-\mathrm{A}-\mathrm{I}$ & 10 & C. albicans & C. albicans \\
\hline $84-\mathrm{A}-\mathrm{II}$ & 20 & $\begin{array}{l}\text { C. albicans } \\
\text { B. pertussis }\end{array}$ & C. albicans \\
\hline 84-A-III & 20 & C. albicans & $\begin{array}{l}\text { C. albicans } \\
\text { B. pertussis }\end{array}$ \\
\hline 84-A-IV & 10 & - & $\begin{array}{l}\text { C. albicans } \\
\text { B. pertussis }\end{array}$ \\
\hline
\end{tabular}

混合接種し, 第 2 次にカンジダ抗原を単独で接種した。 Fig. 2 に示す如き日程で，それぞれ 10 匹を 1 群とし て屠殺, 採血し，血清を分離して PCA 価を測定した。

\section{4. 病理組織学的検查法}

実験 1 の各群につき病理組織学的検索を試みた。す なわち，生存マウスを屠殺，採血後ただちに $10 \%$ ホル マリン水に腹腔, 胸腔を切開いた状態で固定, 切り出 しを行い，心，腎についてのみ光顕標本を作成した。

\section{実験成績}

\section{$\operatorname{IgE}$ 抗体と動脈炎発生頻度}

（1）従来の実験系 (84 A-I 群).すなわち, 第 1 次, 第 2 次ともにカンジダ抗原の単独接種群では PCA 価 1 を示し, 動脈炎発生率は 10 匹中 4 例 (40\%) であっ た (Table 2).

（2）第 1 次にカンジダ抗原と百日咳菌ワクチンを混 合接種し,第 2 次にカンジダ抗原を単独接種した群 (84 A-II 群)では PCA 価 80 を示し, 動脈炎発生率は 15 匹 中 13 匹（87\%）であった。

（3）第 1 次にカンジダ抗原を単独，笑 2 次にカンジ ダ抗原と百日咳菌ワクチンを混合接種した群（84-III 


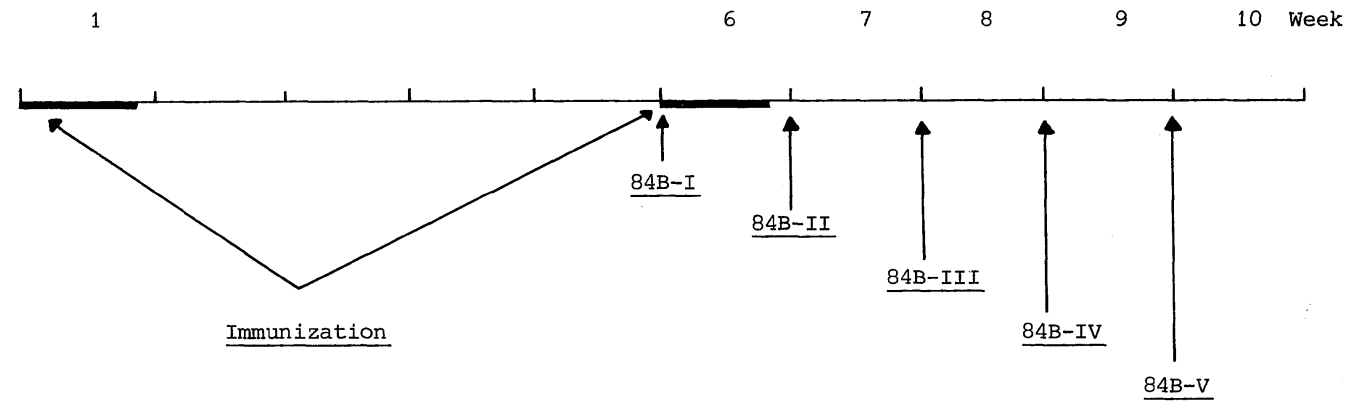

Collection of blood from

Group of mice

Fig. 2. Experimental Schedule (2)

Table 2. Relation of PCA titer and incidence rate of arteritis in mice by candida-extract

\begin{tabular}{cccc}
\hline $\begin{array}{c}\text { Group of } \\
\text { mice }\end{array}$ & $\begin{array}{c}\text { No. of } \\
\text { mice }\end{array}$ & PCA titer & $\begin{array}{c}\text { Incidence of } \\
\text { arteritis }\end{array}$ \\
\hline $84-\mathrm{A}-\mathrm{I}$ & 10 & 1 & $4(40 \%)$ \\
$84-\mathrm{A}-\mathrm{II}$ & 15 & 80 & $13(87 \%)$ \\
$84-\mathrm{A}-\mathrm{III}$ & 11 & 10 & $6(55 \%)$ \\
$84-\mathrm{A}-\mathrm{IV}$ & 7 & negative & $0(0 \%)$ \\
\hline
\end{tabular}

Table 3. Periodical study of PCA titer in mice

\begin{tabular}{|c|c|c|c|c|c|c|}
\hline \multirow{2}{*}{$\begin{array}{l}\text { Group of } \\
\text { mice }\end{array}$} & \multirow{2}{*}{$\begin{array}{c}\text { No. of } \\
\text { mice }\end{array}$} & \multicolumn{5}{|c|}{ PCA titer } \\
\hline & & 10 & 20 & 40 & 80 & 160 \\
\hline $84-B-I$ & 10 & - & - & - & - & - \\
\hline 84-B-II & 10 & + & + & - & - & - \\
\hline 84-B-III & 10 & + & + & + & + & - \\
\hline 84-B-IV & 10 & + & + & + & - & - \\
\hline $84-B-V$ & 10 & + & - & - & - & - \\
\hline
\end{tabular}

群)では PCA 価 10 を示し, 動脈炎発生率は 11 匹中 6 匹（55\%）であった。

（4）第 1 次を無処置とし，第 2 次にカンジダ抗原と 百日咳菌ワクチンを混合接種した群（84 A-IV 群）で は，PCA 及び動脈炎の発生は，7 匹全てが共に陰性で あった。

また, 対照の $56^{\circ} \mathrm{C}, 2$ 時間加温処理した血清の $\mathrm{PCA}$ は全て陰性であった。

病理学的組織像はいわゆる増殖性ないし肉芽腫性動 脈炎といわれるもので，その発生部位（心，腎）と共 に各実験群間での差異は特に認められなかった。

2. IgE 抗体の経時的推移 : PCA 価の経時的推移は それぞれ，第 2 次抗原接種前 (84 B-I 群)では陰性を示
し，抗原接種後 3 日（84 B-II 群）で 20，10 日（84 BIII 群) で 80 ，17 日（84 B-IV 群）で 40，24 日（84 B$\mathrm{V}$ 群) で1であった（Table 3).

\section{考 察}

川崎病の病因は未だ不明であるが，その臨床症状 ${ }^{10)}$ からも, また, 数次にわたる広範な疫学調査 ${ }^{11}$ からも， 今日では何らかの微生物がその発症に関与するらしい とする感染症説が有力視されている。そして, 宿主側 の素因も大きく関与するらしいことも指摘され，その 一つとしてアレルギー性素因が挙げられている。我々 も当初からある種の感染症を疑い, 実験を重ねてきた。 そして, 川崎病患児由来の C. albicans の菌体成分を用 い，マウスに冠動脈炎を作成することに成功した。こ れらの実験的動脈炎は病理組織学的に, 殆んどフィブ リノイド変性を伴わない，增殖性ないしは肉芽腫性動 脈炎であり, その発生部位も冠動脈を始めとして, 腎 葉間動脈，腸間膜動脈及び睪丸動脈など，系統的血管 炎の像を示すこと，そして，これらの血管炎は川崎病 剖検例でみられる血管病変と病理形態学的に，また， 発生部位的に極めて類似することを明らかにしてき

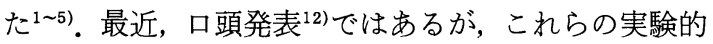
血管炎は川崎病患児の夕ならず，健康児から分離され たC. albicanでも惹起することが明らかとなった。

これらの実験的血管炎の発生機序は明らかではない が，この実験は，その作業仮説1)にもある如く，ある種 の免疫反応の関与を想定したものであり, その成績か らも，ある種の免疫反応を示唆する知見を得ている。 一方, 川崎病患児では，その急性期に IgE 抗体が一過 性に上昇することが知られている(13)。そこで, 我々はこ の実験的動脈炎の発生機序を免疫学的な面から解析す 
る一法として, PCA の手法を用い, $\mathrm{IgE}$ 抗体と動脈炎 発生との関連性及び IgE 抗体の経時的推移などを検 討した。今回の実験では百日咳菌ワクチンの添加接種 群で多くの死亡例を出したが，何机も第 1 次抗原接種 開始後, 数日で死亡したものであり，その死因は百日 咳菌ワクチンの毒性によるものと考劣る。なた，百日 咳菌ワクチンはアジュバント作用が強いことで知ら れ，特に $\operatorname{IgE}$ 抗体産生を増強するといわれる理由から 使用した。

実験 1 の成績から, 従来の実験系でも IgE 抗体の産 生がみられ，この際，百日咳菌ワクチンを添加接種す ることにより, $\operatorname{IgE}$ 抗体が増強されることが明らかと なった。な拈, 同種感作抗体には IgE 抗体の他に, IgG サブクラスの存在が知られている9 $56^{\circ} \mathrm{C}, 2$ 時間加温して PCA 試み, 成績が陰性化した ことによって,これらの成績が $\operatorname{IgE}$ 抗体に由来するこ とを確認した。 また，PCA 価と比例して動脈炎発生頻 度が高まることも確認した。このことは IgE 抗体と動 脈炎発生との間に，何らかの関連性が存在することを 示唆するものである。これらの動脈炎の主な好発部は 冠動脈であるが, 何故に冠動脈が主に侵襲されるのか, その理由は明らかではない，少くとも化学物質的な toxic な反応のみでは説明し難いものと考光る。川崎 病血管病変も主として冠動脈にみられるが，現在，多 くの病理学者たちは，その原因として解剖力学的なも のを考学ている.文献的に, マウスのアナフィラキシー 実験で，その致死的要因を冠動脈の収縮による心機能 不全とする説 ${ }^{14)}$ は, $\operatorname{IgE}$ 抗体の関与するI型アレル ギーにより，冠動脈壁平滑筋の収縮が惹起される可能 性を強く示唆している。また，ミニブタの冠動脈内膜 に予め損傷を加光て和いて，ヒスタミンを投与し，冠 挛縮を惹起せしめたといら報告 ${ }^{15)}$ ある。我々のこれ までの実験でもステロイド剤を使用することにより，

動脈炎発生頻度を減少せしめる成績を得ている 崎病後遺症の一つとして懸念される急性心筇梗塞の原 因は，必ずしも明らかではなく，最近では，その発生 機序の一つとして冠挛縮の関与が推測されている ${ }^{16)}$. これらの実験的知見は，川崎病血管炎のみならず，同 時に急性心筋梗塞の発生機序解明にも寄与寸るか子知 れない.

実験 2 の成績から, IgE 抗体の経時的推移は, 第 2 次 抗原接種後ごく初期に出現し，2週でピークに達し， 3 週では急激に減少を示した。このことは川崎病患児 にみられる IgE 抗体の経時的推移と類似するものと
思われる。

以上， 2 つの実験成績から，カンジダによるマウス の実験的血管炎は, 川崎病血管病変を解明するための 動物モデルとして，その意義を一歩前進せしめたもの と考光る。

稿を終るに臨み, 組織標本作製に御協力を戴いた, 本大学 大橋病院，病理部の臨床検查技師諸氏に対し，深謝致しま す.

また, 本研究には厚生省特定疾患, 系統的血管病変の調査 研究班 (班長, 福田芳郎教授)の研究費を使用させて戴きま した.

\section{文献}

1）村田久雄：カンジタ抗原によるマウスの実験的動 脈炎一川崎病にみられる血管病変との関連に招い て一. 日感染学誌, 52:331-337, 1978.

2) Murata, H.: Experimental Candida-induced arteritis in mice - Relation to arteritis in the MCLS. Microbiol. Immunol., 23 : 825-831, 1979.

3）村田久雄, 飯島 肇, 直汇史郎：カンジタ菌体抽出 物によるマウスの実験的冠状動脈炎に関する研 究. 第 1 報, 真菌誌, $20: 214-219,1979$.

4）村田久雄, 飯島 肇, 直江史郎, 増田弘毅：カンジ 夕菌体抽出物によるマウスの実験的冠状動脈炎に 関する研究. 第 2 報. 真菌誌, $21 ： 131-136,1980$.

5）直江史郎, 跡部俊彦, 村田久雄, 飯島 肇, 増田弘 毅：カンジタ菌体抽出物投与による動脈炎作成実 験一とくに川崎病のモデルとして. 医学のあゆみ, $123: 77-88,1982$.

6）直江史郎，村田久雄：Candida 菌体成分投与に上 る血管炎, 難治疾患モデルと動物実験（京極方久 編), p. 543-552, ソフトサイエンス社, 1984.

7) Murata, H. and Naoe, S.: Candida extract induced arteritis as an animal model for Kawasaki disease. "Toxigenic fungi-Their Toxins and Health Hazard", p. 348-356, Kodansha, Tokyo, 1984.

8）金子義德：百日核，微生物検査必携，p. 287-296, 日本公衆衛生協会, 1968 .

9）多田富雄：過敏症の測定法。医化学実験法講座 4, 免疫化学, p. 235-245, 中山書店, 1972.

10）川崎富作：指趾の特異的落屑を伴う小児の急性熱 性皮膚粘膜淋巴腺症候群。アレルギー, $16 ： 178$ $-222,1967$.

11）柳川 洋, 柴田茂男, 重松逸造：川崎病病因への接 近一疫学的立場から. 小児科, $24: 271-280,1983$.

12）直江史郎, 安藤充利, 涉谷和俊, 跡部俊彦, 村田久 雄：川崎病類似病変作成実験に関する研究一いく つかの患児由来 C. albicans 菌株の検討. 第73回日 本病理学会総会, 東京, 1985 . 
13）草川三治, Douglas, C.H. : 川崎病の IgE につい て.川崎病 (MCLS) 研究のあゆみ, p. 120-122, 近代出版, 1976.

14）鈴田達男：ハッカネズミのアナフィラキシーの機 序に関する病態生理学的研究. 東京医誌, 67 ： 1463-1485, 1959.
15) Shimokawa, H., Tomoike, H., Nabeyama, S., Yamamoto, H. and Araki, H.: Coronary artery spasma induced in atheroscloerotic miniature swine, Science, $221: 560-561,1983$.

16) 安田寿一: 循環器病学. 日本医事新報, 3125 : 2-17, 1984.

\title{
Relationship between IgE Antibody and the Incidence of Arteritis by Candida Extract in Mice
}

\author{
Hisao Murata, Hajime Iijima, Shiro Naoe* and Toshihiko Atobe* \\ Department of Public Health, Toho University School of Medicine, 5-21-16, Omori-nishi, Ota-ku, Tokyo 143 \\ * Research Laboratory of Pathology, Toho University Ohashi Hospital, 2-17-6, Ohasi, Meguro-ku, Tokyo 153
}

It is known that a spontaneous increase in IgE antibody is seen in the early stage of Kawasaki disease. Based on previous experiments of Candida extract-induced arteritis in mice, an investigation of the relationship between IgE antibody and the incidence of arteritis was carried out using the PCA method. It was confirmed that IgE antibody (PCA titer 1) was produced in response to two round immunization with alkali-extracted Candida antigen. It was also shown that the production of $\operatorname{IgE}$ antibody increased when Candida antigen was injected together with Bordetella pertussis vaccine. In this case, mice in a group which had $B$. pertussis vaccine in a first round immunization with Candida antigen showed higher IgE antibody titer than those in a group which had $B$. pertussis vaccine in a second round immunization. In each of three groups, the incidence of arteritis was $40 \%, 87 \%$ and $55 \%$ respecitvely. However, the mice in a group which only one round injection of a mixture of Candida antigen and B. pertussis vaccine showed neither PCA reaction nor incidence of arteritis. This result suggests that $\operatorname{IgE}$ antibody may be related to the incidence of arteritis.

The time course of IgE antibody production was also studied. The IgE antibody (PCA titer 20) appeared on the third day after the second round injection and reached a peak (PCA titer 80 ) on the 10th day, then decreased on the 24 th day (PCA titer 1). It was also shown that the production of IgE antibody in this experiment resembled that in Kawasaki disease. 